\title{
ACEHNESE ARCHAIC WORDS IN HIKAYAT: AN EARLY INFLUENTIAL LITERARY WORK
}

\author{
Zulfadli Abdul Aziz ${ }^{1 *}$; Syamsul Bahri Yusuf²; Faisal Mustafa ${ }^{3}$; Siti Munawarah ${ }^{4}$ \\ ${ }^{1}$ Associate Professor, English Education Department, Faculty of Teacher Training and Education, Universitas Syiah Kuala \\ ${ }^{2,3,4}$ English Education Department, Faculty of Teacher Training and Education, Universitas Syiah Kuala \\ Jl. Teuku Nyak Arief No. 441, Kopelma Darussalam, Kota Banda Aceh, Aceh 23111, Indonesia \\ 17zulfadli.aziz@unsyiah.ac.id; ${ }^{2}$ syb_ina@yahoo.com; ${ }^{3}$ faisal.mustafa@unsyiah.ac.id; ${ }^{2}$ siti030894@gmail.com
}

Received: $12^{\text {th }}$ June $2020 /$ Revised: $05^{\text {th }}$ July 2020/Accepted: $24^{\text {th }}$ August 2020

How to Cite: Aziz, Z. A., Yusuf, S. B., Mustafa, F., \& Munawarah, S. (2020). Acehnese archaic words in hikayat: An early influential literary work. Lingua Cultura, 14(2), 161-169. https://doi.org/10.21512/lc.v14i2.6498

\begin{abstract}
The research aimed at finding out the Acehnese archaic words and their non-archaic alternatives that younger speakers often utter today. Several Acehnese original lexical items were no longer understood by the younger generation, and thus it was expected that some words to disappear without proper documentation. Hikayat Prang Sabi (Sabil War Sage), an early literary work in Acehnese, was the source of archaic words for the research. Therefore, the research design applied a descriptive qualitative method. The data consisted of 54 suspected archaic words from Hikayat Prang Sabi that were distributed to 20 speakers of Acehnese who lived in the Pidie regency. They were divided into two age groups consisting of 20 to 25 years old and 26 to 30 years old. They were asked to verify the suspected archaic words. The research results show that there are five archaic words and 49 semi-archaic words have found in the Hikayat.
\end{abstract}

Keywords: archaic words, Acehnese archaic words, literary work, Hikayat Prang Sabi

\section{INTRODUCTION}

Language change is a symptom that cannot be avoided (Bowern, 2015). The change mostly spreads through the language's grammar and it will affect one context after another (De Smet, 2016). It can be easily spotted that the language used by the new generation is different from the language used by the older generation. It appears that a change of linguistic variant in a community, in general, is more regular than that of individual speakers' changes (Baxter \& Croft, 2016). Written documents have been used as media to reveal the language change for many centuries (Sankoff, 2018).

As a country with very high language diversity, Indonesia can have different languages in one region (Rahmi, 2015). Aceh, for example, the northernmost province of Indonesia, has several languages. To communicate with different language speakers, bahasa Indonesia is usually used. The contact of Acehnese languages with bahasa Indonesia, which is the national language of the nation, then, cannot be avoided (Chairuddin, 2018). It is quite common to observe that the younger generation has less frequently used
Acehnese (Al-Auwal, 2017), which can affect the changes in the language over time. The Acehnese people now feel more comfortable to speak Indonesian than their mother tongue (Aziz \& Amery, 2016; Aziz, Yusuf, \& Menalisa, 2020).

Historical events and values are usually recorded in literary works (Öztaş, 2018). In traditional literary works such as hikayat, poetry, folklore, some dated words can also be found. However, most of these words have been unfamiliar to the speaker of the language. They become archaic to the younger generation as they are now mostly exposed to the national language, bahasa Indonesia. Therefore, in the research, the archaic words from Hikayat Prang $\mathrm{Sabi}$, one of the most influential literary works in Aceh literature, are explored. This hikayat has motivated jihadists to fight in a war. It is appointed as a base ideology and motivation in driving out the Dutch for Aceh people. The research aims to find out words in Hikayat Prang Sabi, which are considered archaic by Acehnese speakers, in addition, to find out the nonarchaic alternatives for those archaic words in the literary work.

Language change constantly works (Clark, 
2016). It is the alteration process of linguistic features such as phonetics, morphology, syntax, and semantics (Shabina, 2011), and the changes could affect these features. Among those features, a change in the lexical item is the focus of the current research.

Lexical change is one of the aspects of language change that is most noticeable (Rizka \& Zainuddin, 2016). This change can be resulted from the language contact in speakers' bilingual or multilingual context, which influences all linguistic aspects with lexical items as the most affected (Shabina, 2011). Technological innovations, such as computer technology, contribute to new word formation in a language (Sun, 2016). Due to the existence of new inventions and changes in every language, people usually need new words. The establishment of new vocabulary may happen through word-formation processes, such as acronyms, blending, clipping, coinage, functional shift, and eponymy (Jannedy, Poletto, \& Weldon, 1994).

In acronyms, words are formed from a combination of the initial letters of a word or a phrase that can be pronounced (Jannedy, Poletto, \& Weldon, 1994). The acronym process usually occurs by combining letters or syllables or other parts that can be pronounced or read. Examples of this word-formation process are NATO, an acronym for 'The North Atlantic Treaty Organization' or NASA for 'National Aeronautics and Space Administration'.

Word blending can be created by joining two words to become a new one (Ratih \& Gusdian, 2018). The blends can be made by fusing at least two words by joining together parts of source words (Čolić, 2015). The combination of two words is usually in the form of the first initial of one word is combined with the end of another word (Nurhayati, 2016), such as the word smog, which derives from smoke and fog, brunch from breakfast and lunch, and travelogue from travel and monologue. In addition to blending, words can be formed by the process of clipping where a part of the word is cut itself; it may be the first part, middle or last part of the word (Moehkardi, 2017). This occurs when a word of more than one syllable word is reduced to a shorter version, for example, the word 'exam', which has been clipped from the 'examination', 'dorm' from the 'dormitory', or 'ad' from the 'advertisement'.

Coinage is a word-formation process in which new words are completely created in a language (Triwahyuni, Imranuddin, \& Zahrida, 2018). The new words are usually used to name new invented objects. Examples of words are created through this process, for instance, Xerox, Kodak, Exxon, Kleenex, Aqua, Sanyo, Rinso. Words are usually created through the functional shift, which is also known as a conversion. It is the process of changing the word class without changing the word form (Jannedy, Poletto, \& Weldon, 1994). The words formed by a functional shift in English include the nouns used as verbs such as 'paper' into 'to paper' (paper this room), 'shape' into 'to shape' (shape the dough into a ball!), and 'water' into 'to water' (mother is watering the flowers in the garden).
An eponym is another way of forming words by using a person's name for other objects such as places, discoveries, and activities (Multazim \& Nurdin, 2019). The object that can be named after a person usually has an important influence, such as 'Washington, D.C.' after 'George Washington', and 'District of Columbia' after 'Christopher Columbus'. Lexical change is not only marked by the emergence of new vocabulary, but it can also be marked by the loss of vocabulary (Vejdemo \& Hörberg, 2016). Because a language is never stable, old vocabulary changes over time, new vocabulary appears in a language, and a certain number of these old words are rarely used, and these words are known as archaic words.

Archaism is defined as an old and outdated word or expression (Awe \& Fanokun, 2018). Archaism, which is commonly related to vocabulary though not always, is a linguistic form usually used in the past time, but now it is out of date (Traxel, 2012). Moreover, many archaic words have been changed their meaning or are no longer used by speakers in everyday life (Karagulova et al., 2016). Archaic words can be simply distinguished from obsolete words. The term 'obsolete' means a word that is completely out of use (Rababah, 2016). Obsolete words can also be used in conversation to give the impression of humor.

The definition between 'archaic' and 'obsolete' seems unclear because it is hard to decide which group this word belongs to, as reflected in Antrushina, Afanasyeva, \& Morozova (2008). Some people give both words the same meaning, while others state that obsolete is the term for the words that totally outdated (Antrushina, Afanasyeva, \& Morozova, 2008). In contrast to obsolete, the archaic term is still known today as a part of the language (Traxel, 2012). It may be found in special contexts, such as law or special writing styles, namely Scriptures. Sometimes modern writers use archaic words to give their writings an oldfashioned flavor. In this dictionary, the term archaic has the same sense of meaning to obsolete that is a word only found in writings of an earlier time or in modern writings that imitate earlier writing style. From that explanation, it can be concluded that the definition does not show a clear distinction.

Thus, in the research, the researchers agree that the notion of archaic and obsolete is the same because both words have the same definition, i.e., they are old words or ancient words that are no longer used in daily conversation, but they can only be found in literary or other written documents. Some examples of archaic words in English are 'bourn' (boundary), 'morrow' (the next day), 'fain' (happy, inclined, pleased), and sooth (truth, reality, in truth).

Hikayat is one of the most favored entertainments by Acehnese people until the early $20^{\text {th }}$ century. Hikayat is a fiction story in the form of prose that is closely related to indigenous beliefs (Ekawati, 2015). However, in the context of Aceh, this literary work is composed by ulama or Islamic scholars, using the Acehnese language, which is arranged in poetic poetry form and contains not only fiction and legend but also 
moral education and religious teachings. It functions as jihad 'holy war' spirit, aesthetic, entertainment, education, and literacy eradication (Khadijah, 2013). Hikayat in Aceh is generally anonymous and usually written with the jawi letter, Malay written in Arabiclike alphabet. Jawi letters are commonly used for written prose in traditional Acehnese societies, such as religious textbooks, as well as other documents such as passports, laws, and contracts (Lubis, 2016).

One of the most influential hikayat for Aceh people is Hikayat Prang Sabi, which was written in the $19^{\text {th }}$ or the early $20^{\text {th }}$ century during the Dutch colonialism in Aceh (Masri, Suprayitno, \& Ratna, 2018). This hikayat is named Hikayat Prang Sabi (or also called 'the story of the war in the path of God') because fighting against the infidels (Dutch) is regarded as jihad, and Hikayat Prang Sabi is not the same as any other fiction hikayats because it tells the story mostly related to battles of Aceh fighters and uplifting sermon against the Dutch starting 1873 (Taslim, 2013). Hikayat Prang Sabi has two genres, i.e., tambéh (warning and advice), which mostly contains matters related to great jihad that is against ourselves, and epic, which is about small jihad, i.e., the war in Aceh (Nushur \& Astutie, 2019). The power of words in Hikayat Prang Sabi is strong enough to motivate Aceh people for syahid 'martyr' against the Dutch (Lubis, 2016). In addition, this hikayat is regarded as a dangerous weapon for the Acehnese by the Dutch military government, so that it was forbidden to recite, save, or propagate it (Hasjmy, 1977).

Many texts of Hikayat Prang Sabi are anonymous. The manuscript of this hikayat was written in 1710 and 1834, several decades before the war against the Dutch. These manuscripts are stored in the library of Leiden State University in Holland. However, the oldest text which was famous in the battle time was the Hikayat Prang Sabi written by Teungku Chik Panté Kulu. Based on its content, Hikayat Prang Sabi can be divided into two parts. The first part consists of memorial verses and advice to fight against the Dutch, with the insertion of verses of the Qur'an (The Holy Book of Islam) and Hadith (the prophet Muhammad's words and actions). The second part consists of verses that tell four ancient Islamic holy wars, i.e., Abeudo Wahed (Ainul Mardhiah), Mecca's holy war against the Abyssinian, black Saet Saleumi, and reborn slave Muhammad Amien.

\section{METHODS}

In the research, the data are obtained from the book entitled Seumangat Atjeh: Hikayat Prang Sabi (The Spirit of Aceh: Hikayat Prang Sabi), compiled by Abdullah Arif. This book was published in Koetaradja (now Banda Aceh) by Pencetakan Aceh Negara Republik Indonesia in 1946. Consequently, the most appropriate method to answer the aforementioned research questions is a descriptive qualitative method (Kim, Sefcik, \& Bradway, 2017; Nassaji, 2015).
The researchers create suspected archaic words through the introspection method. The words are included in the list if the researchers, one of whom is 24 years of age, has not heard the word or does not know its meaning. After a careful examination that they are suspected becoming archaic words, 59 words are selected to be validated by 20 respondents in the 20-30 age range who are native speakers of the Pidie dialect of Acehnese and live in Pidie regency. The respondents selected used Acehnese as their First Language (L1) in daily conversation among their family and community members, although they are fluent in bahasa Indonesia (Second Language/L2). The research is conducted by distributing the suspected archaic word list based on the researchers' examination and analysis to the respondents.

The respondents are asked the list of the words from the distributed questionnaires whether they have heard each word in the list and whether they know what it means. Any word in the list is considered archaic if none of the respondents have heard it and semi-archaic if at least one has heard the word used by other speakers, but they do not know its meaning. The words which the respondents could identify as non-archaic are eliminated from the analysis. In drawing a conclusion about the archaic words and their level of archaicity, the data are divided into two groups based on the age of the respondents. The first group is the respondents who are between 20 and 25 years of age, and the second between 26 and 30 years of age. Each group consists of 10 respondents. This data categorization, which is based on the age of the respondents, is considered because young speakers tend to experience more language contact with bahasa Indonesia than their older counterparts.

To determine whether a validated archaic or semi-archaic word has a non-archaic alternative, the researchers consult an old dictionary, Kamus Aceh Indonesia. The data from this source are used to construct the alternative of the archaic and semiarchaic words found and validated by the respondents in Hikayat Prang Sabi.

\section{RESULTS AND DISCUSSIONS}

The archaic data presented to the younger Acehnese speakers contain 59 words which are predicted archaic words. However, five of them are not archaic words, and thus they are eliminated in the research finding. Therefore, the number of words included in the analysis is 54 . The status of archaic words (the level of their archaicity) in the research is determined based on the number of speakers who considered them archaic or semi-archaic. Hence, the results are divided into three parts, that is archaic, semi-archaic, and non-archaic words. A word is considered archaic if it has never been heard or used by the respondents. A semi-archaic word is a word that has only been heard by the respondents, but they never use it and do not know its meaning. Apart from the two 
categories, other words are considered non-archaic words. There are 20 speakers selected in the research and divided into two groups according to their age, namely the age group of 20 to 25 and 26 to 30 .

From 54 referred to as archaic words in Hikayat Prang Sabi, a total of five words are considered archaic by the respondents. It can be seen in Table 1 .

Table 1 Archaic Words

\begin{tabular}{|c|c|c|}
\hline \multicolumn{2}{|c|}{ Words } & Meaning \\
\hline lanti & /lanti/ & later, wait \\
\hline haneng & /hanẽy/ & $\begin{array}{l}\text { clear, bright, fresh, holy, } \\
\text { pure }\end{array}$ \\
\hline jilila & /jilila/ & jump, dance \\
\hline ngeuren & /yũrey/ & anger, wrath, jealousy \\
\hline suang & /suan/ & bad luck, unfortunate, woe \\
\hline
\end{tabular}

In addition, there are 49 words considered semi-archaic words by the respondents. There are four categories of semi-archaic words based on lexical word classes. Nine semi-archaic verbs are identified by the respondents, as can be seen in Table 2 .

Table 2 Semi-archaic Verbs

\begin{tabular}{|c|c|c|}
\hline \multicolumn{2}{|c|}{ Words } & Meaning \\
\hline seumurat & /swmũrat/ & to tell a story \\
\hline meutatah & /mütatah/ & sculpt, carve \\
\hline teujali & /twjali/ & revealed, real \\
\hline teugoe-goe & /twgəagวа/ & remembered, worried \\
\hline manyoh & /mãñ̃h/ & craving \\
\hline meungo & 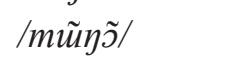 & buzzing (?) \\
\hline meuandam & /mũ̃?andam/ & make up \\
\hline geuseundi & /guswndi/ & neatly arranged, frolic \\
\hline meusuji & /mи̃ssuil/ & neatly arranged (?) \\
\hline
\end{tabular}

Besides verbs, there are also 15 semi-archaic adjectives found in Hikayat Prang Sabi according to the respondents. It can be seen in Table 3 .

Table 3 Semi-archaic Adjectives

\begin{tabular}{|c|c|c|}
\hline \multicolumn{2}{|c|}{ Words } & \multirow{2}{*}{\begin{tabular}{l}
\multicolumn{1}{c}{ Meaning } \\
exact, appropriate, \\
true
\end{tabular}} \\
\hline reumbang & /rumbay/ & \\
\hline samlakoe & /samlakəə/ & handsome \\
\hline sambinoe & /sambiñ̃a/ & lovely, beautiful \\
\hline$t i j i$ & /tiji/ & fast \\
\hline meulo-lo & /mũlolo/ & shiny \\
\hline leunteng & /luntey/ & beauty, handsome \\
\hline
\end{tabular}

Table 3 Semi-archaic Adjectives (Continued)

\begin{tabular}{|c|c|c|}
\hline \multicolumn{2}{|c|}{ Words } & Meaning \\
\hline teugageung & /tmgaguəy/ & supine, lying \\
\hline lindan & /lindan/ & very longing \\
\hline mеијеureulah & /mи̃uдurulah/ & sparkling \\
\hline$a j a b$ & /Pajab/ & $\begin{array}{l}\text { miraculous, } \\
\text { amazing magical, } \\
\text { astonishing }\end{array}$ \\
\hline wangsa & /waysal & young \\
\hline beewan & /bc:wan/ & $\begin{array}{l}\text { fragrant, odor, } \\
\text { incense }\end{array}$ \\
\hline peulanggi & /pulaygi/ & colorful \\
\hline leubui & /lubui/ & sleepy \\
\hline ranom & /rañ̃m/ & friendly, gentle \\
\hline
\end{tabular}

There is one semi-archaic word functioning as an adverb found in Hikayat Prang Sabi, i.e., sret / srẽt/or sreut/srut/ 'unexpectedly, at once'. Moreover, there are 24 semi-archaic nouns found in Hikayat Prang Sabi, as can be seen in Table 4.

Table 4 Semi-archaic Nouns

\begin{tabular}{|c|c|c|}
\hline \multicolumn{2}{|c|}{ Words } & Meaning \\
\hline bahgi & /bahgi/ & part, fate \\
\hline seunaroe & /swnãroal & comrade in arms \\
\hline kande & /kandel & $\begin{array}{l}\text { candlestick, candle } \\
\text { holder }\end{array}$ \\
\hline gambang & /gambay/ & xylophone \\
\hline pari & /pari/ & spirit, name of star \\
\hline tanjong & /tanjoy/ & cape, headland \\
\hline keumala & /kumãla/ & jewel \\
\hline bulueng & /buluәу/ & part, portion \\
\hline keutanggi & /kutaygi/ & burning odors, incense \\
\hline rihan & /rihan/ & sweet basil \\
\hline pudoe & /pudəa/ & gemstone \\
\hline reuleueng & /rulшәу/ & cliff \\
\hline cawareudi & /cawarmdi/ & $\begin{array}{l}\text { glistening substances } \\
\text { coating the gold }\end{array}$ \\
\hline santeue & /santua/ & hanging \\
\hline sirungkhe & /siruykhel & a series (?) \\
\hline linte & /linte/ & son in law \\
\hline bangsi & /baysi/ & flute \\
\hline duli & /duli/ & $\begin{array}{l}\text { dust, designation to the } \\
\text { king }\end{array}$ \\
\hline meuligi & /mũligi/ & palace \\
\hline lagam & /lagam/ & kind of large tree \\
\hline bunyoe & /buñ̃a/ & sound \\
\hline peundeng & /pundey/ & jewelry belt \\
\hline keuta & /kmta/ & bed \\
\hline gahru & lgahrul & gaharu wood \\
\hline
\end{tabular}


From 49 semi-archaic words, there are three words which are often used by the speakers, that is tiji 'fast', keumala 'jewel', and tanjong 'cape', 'headland'. These words are now not used as a common noun, but they are names of places in the Pidie district. Although the words are commonly used as proper nouns, Acehnese people in Pidie no longer know their meaning. Therefore, these words are categorized into semi-archaic words. Moreover, there are also three semi-archaic words whose meanings can no longer be found in any dictionary, i.e., sirungkhe 'a series', meungo 'buzzing', and meusuji 'neatly arranged'. In this research, their meanings are predicted based on the context within Hikayat Prang Sabi.

The status of Acehnese archaic words in Hikayat Prang Sabi based on the respondents in different age groups seems different. Table 5 shows that from the data of 54 words, 12 archaic words are identified by the respondents in the age group of 20-25 years, but only five are true for those in the age group of 26-30. This suggests that the younger the age of the Acehnese speakers, the higher number of words is considered archaic.

In Table 5, the respondents in the age group of 20-25 consider 12 words as archaic, and seven are semi archaic for the older age group (26-30). Less than 50\% of the participants (1-4) in the age group have heard the words used by other people, but they do not know their meaning. The words considered semi-archaic by respondents in both age groups include verbs, adjectives, and nouns. The numbers of respondents who reported hearing the words for each word class are presented in Table 6 . Based on Table 6 , the number of respondents hearing the semi-archaic words does not show much difference either for each word class or for combined data.

Table 5 Archaic Words According to Different Age Groups

\begin{tabular}{clcccccc}
\hline \multirow{2}{*}{ No } & \multirow{2}{*}{ Words } & \multicolumn{3}{c}{ Age 20-25 } & \multicolumn{3}{c}{ Age 26-30 } \\
\cline { 2 - 7 } & Archaic & Semi-archaic & Heard by & Archaic & Semi-archaic & Heard by \\
\hline 1 & lanti & $\sqrt{ }$ & - & 0 & $\sqrt{ }$ & - & 0 \\
2 & haneng & $\sqrt{ }$ & - & 0 & $\sqrt{ }$ & - & 0 \\
3 & jilila & $\sqrt{ }$ & - & 0 & $\sqrt{ }$ & - & 0 \\
4 & ngeuren & $\sqrt{ }$ & - & 0 & $\sqrt{ }$ & - & 0 \\
5 & suang & $\sqrt{ }$ & - & 0 & $\sqrt{ }$ & - & 0 \\
6 & lindan & $\sqrt{ }$ & - & 0 & - & $\sqrt{ }$ & 1 \\
7 & duli & $\sqrt{ }$ & - & 0 & - & $\sqrt{ }$ & 1 \\
8 & keutanggi & $\sqrt{ }$ & - & 0 & - & $\sqrt{ }$ & 2 \\
9 & gahru & $\sqrt{ }$ & - & 0 & - & $\sqrt{ }$ & 2 \\
10 & beewan & $\sqrt{ }$ & - & 0 & - & $\sqrt{ }$ & 4 \\
11 & wangsa & $\sqrt{ }$ & - & 0 & - & $\sqrt{ }$ & 4 \\
12 & ajab & $\sqrt{ }$ & - & 0 & - & & \\
\hline
\end{tabular}

Table 6 Number of Respondents Reporting Hearing Semi-archaic Words

\begin{tabular}{cccccccccc}
\hline & \multicolumn{8}{c}{ Number of semi-archaic words } \\
\cline { 2 - 9 } Heard by & \multicolumn{2}{c}{ Verbs } & \multicolumn{2}{c}{ Adjectives } & \multicolumn{3}{c}{ Nouns } & \multicolumn{3}{c}{ Total } \\
\cline { 2 - 9 } & $\mathbf{2 0 - 2 5}$ & $\mathbf{2 6 - 3 0}$ & $\mathbf{2 0 - 2 5}$ & $\mathbf{2 6 - 3 0}$ & $\mathbf{2 0 - 2 5}$ & $\mathbf{2 6 - 3 0}$ & $\mathbf{2 0 - 2 5}$ & $\mathbf{2 6 - 3 0}$ \\
\hline 1 & 1 & 0 & 0 & 0 & 5 & 1 & 6 & 1 \\
2 & 3 & 4 & 0 & 0 & 2 & 4 & 5 & 8 \\
3 & 2 & 1 & 2 & 4 & 5 & 5 & 9 & 10 \\
4 & 3 & 3 & 4 & 1 & 4 & 5 & 11 & 9 \\
5 & 0 & 1 & 2 & 0 & 1 & 1 & 3 & 2 \\
6 & 0 & 0 & 3 & 1 & 1 & 2 & 4 & 3 \\
7 & 0 & 0 & 0 & 3 & 1 & 0 & 1 & 3 \\
8 & 0 & 0 & 0 & 1 & 0 & 0 & 0 & 1 \\
9 & 0 & 0 & 0 & 0 & 0 & 0 & 0 & 0 \\
10 & 0 & 0 & 0 & 0 & 2 & 3 & 2 & 3 \\
\hline
\end{tabular}


The research has found that the archaic and semi-archaic words are replaced mostly by synonyms. It is two words with similar meanings and can be interchangeably used in the same context without changing the meaning. The existence of synonym word form can lead to the status of the archaic word, especially when the equivalent form is used more frequently as the replacement word in the community. The synonyms which replaced the archaic and semiarchaic words are mostly found in the dictionary. This type of substitution words for archaic words is also found in Minangkabaunese, the native language spoken in West Sumatra, Indonesia (Azim \& Jufrizal, 2020). The replacements for the archaic and semiarchaic words are presented in Table 7.

Table 7 Replacements of Archaic Words

\begin{tabular}{|c|c|c|}
\hline Archaic word & Meaning & $\begin{array}{c}\text { Non-archaic } \\
\text { alternative }\end{array}$ \\
\hline haneng / hanẽy/ & $\begin{array}{l}\text { clear, bright, } \\
\text { fresh, holy, } \\
\text { pure }\end{array}$ & gléh /gleh/ \\
\hline jilila / jilila/ & jump, dance & $\begin{array}{l}\text { gröb /grob/, chèn } \\
\text { /chen/, lumpat / } \\
\text { lumpat/, tajö, }\end{array}$ \\
\hline lanti / lanti/ & later, wait & $\begin{array}{l}\text { prèh /preh/, } \\
\text { keumiet / } \\
\text { kumimat/, enteuk } \\
\text { /untu?/, entreuk } \\
\text { /untru?/ }\end{array}$ \\
\hline $\begin{array}{l}\text { ngeurén / } \\
\text { yũrey/ }\end{array}$ & $\begin{array}{l}\text { anger, wrath, } \\
\text { jealousy }\end{array}$ & $\begin{array}{l}\text { beungèh / } \\
\text { bunyẽh/, gigéng / } \\
\text { gigen/, bingkèng } \\
\text { /binkey/, cemuru }\end{array}$ \\
\hline suang / suay/ & $\begin{array}{l}\text { bad luck, } \\
\text { unfortunate, } \\
\text { woe }\end{array}$ & $\begin{array}{l}\text { neuh'aih / } \\
\text { nũhãih/, cilaka / } \\
\text { cilaka/ }\end{array}$ \\
\hline
\end{tabular}

All the archaic words in Table 7 have alternatives, which are still commonly used. Some of the alternatives have the same meaning as archaic words so that they can be used in different contexts. Most of the alternatives are Acehnese words, but some are borrowed from Bahasa Indonesia, such as lumpat /lumpat/ 'jealous' as the alternative for jilila /Jilila/, which is a naturalized borrowing word from Bahasa Indonesia lompat/lompat/. In addition to the archaic words, the semi-archaic words also have nonarchaic alternative words that are Acehnese words and borrowed words from bahasa Indonesia that can be seen in Table 8.

In Table 8 , all of the data have alternatives except two, that is, lagam 'kind of large tree' because it is considered as a term, and tanjong. All of the alternatives are words from Acehnese, but there are some words borrowed from bahasa Indonesia. The borrowing words from bahasa Indonesia as the alternatives for semi-archaic words include pure borrowing and naturalized borrowing. An example of pure borrowing from Indonesian is rindu, kangen 'very longing', as the replacement for lindan. In addition, the word that is considered as naturalized borrowing involves sound change such as canték /cante?/ 'lovely', 'beautiful' as the replacement of sambinoe. It is a naturalized borrowing word from bahasa Indonesia cantik/canti?/ 'lovely', 'beautiful'. Another naturalized borrowing involves the addition of prefix such as $m e u-/ \mathrm{mu} /$ in meukeulap-keulip 'sparkling' as the alternative for meujeureulah naturalized borrowing from bahasa Indonesia kerlap-kerlip /kərlap-kərlip/ 'sparkling'.

Table 8 Non-archaic Alternative for Semi-archaic Words

\begin{tabular}{|c|c|c|}
\hline Word & Meaning & $\begin{array}{l}\text { Non-archaic } \\
\text { alternative }\end{array}$ \\
\hline $\begin{array}{l}\text { lindan /lin- } \\
\text { dan/ }\end{array}$ & very longing & $\begin{array}{l}\text { meuchèn / } \\
\text { muchẽn/, rindu / } \\
\text { rindu/, kangen / } \\
\text { kanãn/ }\end{array}$ \\
\hline duli /duli/ & $\begin{array}{l}\text { dust, designa- } \\
\text { tion to the king }\end{array}$ & $\begin{array}{l}\text { abèe /abcə/, raja / } \\
\text { raja/ }\end{array}$ \\
\hline $\begin{array}{l}\text { keutanggi / } \\
\text { kutangi/ }\end{array}$ & $\begin{array}{l}\text { burning odors/ } \\
\text { incense }\end{array}$ & $\begin{array}{l}\text { töt /tət/, teut } \\
\text { keumunyan /tuit } \\
\text { kumunan/ }\end{array}$ \\
\hline gahru /gahru/ & gaharu wood & $\begin{array}{l}\text { kayèe gaharu / } \\
\text { kajeə gaharu/ }\end{array}$ \\
\hline $\begin{array}{l}\text { beewan / } \\
\text { be:wan/ }\end{array}$ & $\begin{array}{l}\text { fragrant, odor, } \\
\text { incense }\end{array}$ & $\begin{array}{l}\text { wangi-wangian / } \\
\text { wayi wanijan/ }\end{array}$ \\
\hline $\begin{array}{l}\text { wangsa / } \\
\text { waysal }\end{array}$ & young & muda /muda/ \\
\hline ajab/Pajab/ & $\begin{array}{l}\text { miraculous, } \\
\text { amazing }\end{array}$ & $\begin{array}{l}\text { hayeue /hajuə/, } \\
\text { àjayéb / Rajajep/ }\end{array}$ \\
\hline $\begin{array}{l}\text { santeue / } \\
\text { santmal }\end{array}$ & hanging & $\begin{array}{l}\text { sawak/sawa?/, } \\
\text { sangköt /sankot/, } \\
\text { lhat /lhat/ }\end{array}$ \\
\hline $\begin{array}{l}\text { teujali / } \\
\text { tujali/ }\end{array}$ & revealed, real & $\begin{array}{l}\text { leumah /lumãh/, } \\
\text { deuh /duh/ }\end{array}$ \\
\hline $\begin{array}{l}\text { cawareudi/ } \\
\text { cawarmdi/ }\end{array}$ & $\begin{array}{l}\text { glistening } \\
\text { substances } \\
\text { coating the gold }\end{array}$ & $\begin{array}{l}\text { batée kilat /bateə } \\
\text { kilat/ }\end{array}$ \\
\hline $\begin{array}{l}\text { lagam / } \\
\text { lagam/ }\end{array}$ & $\begin{array}{l}\text { kind of large } \\
\text { tree }\end{array}$ & - \\
\hline $\begin{array}{l}\text { bulueng / } \\
\text { buluay/ }\end{array}$ & part, portion & bagi /bagi/ \\
\hline $\begin{array}{l}\text { sirungkhe / } \\
\text { sirugkhe/ }\end{array}$ & a series & $\begin{array}{l}\text { karang(an) / } \\
\text { karay(ãn)/, serang- } \\
\text { kai /seraykai/ }\end{array}$ \\
\hline $\begin{array}{l}\text { manyoh / } \\
\text { mãñ̃h/ }\end{array}$ & craving & h'eut /hũt/ \\
\hline linte /linte/ & son in law & $\begin{array}{l}\text { meulintèe / } \\
\text { mũlintea/ }\end{array}$ \\
\hline
\end{tabular}


Table 8 Non-archaic Alternative for Semi-archaic Words (Continued)

\begin{tabular}{|c|c|c|}
\hline Word & Meaning & $\begin{array}{l}\text { Non-archaic } \\
\text { alternative }\end{array}$ \\
\hline $\begin{array}{l}\text { meuligi / } \\
\text { mũligi/ }\end{array}$ & palace & $\begin{array}{l}\text { meuligoe / } \\
\text { mũligoə/, istana / } \\
\text { istanã// }\end{array}$ \\
\hline $\begin{array}{l}\text { meuandam / } \\
\text { müPandam/ }\end{array}$ & make up & $\begin{array}{l}\text { meungui /mũyũi/, } \\
\text { solek /sole?/ }\end{array}$ \\
\hline $\begin{array}{l}\text { geuseundi/ } \\
\text { guswindi/ }\end{array}$ & $\begin{array}{l}\text { neatly arranged, } \\
\text { frolic }\end{array}$ & $\begin{array}{l}\text { susön /suson/, } \\
\text { meuseunda / } \\
\text { mũsunda/, ma- } \\
\text { yang /mãjay/ }\end{array}$ \\
\hline $\begin{array}{l}\text { meusuji / } \\
\text { müsuji/ }\end{array}$ & neatly arranged & $\begin{array}{l}\text { susön /suson/, } \\
\text { tumpök /tumpo?/, } \\
\text { atö /ato/, tindéh / } \\
\text { tindeh/ }\end{array}$ \\
\hline $\begin{array}{l}\text { sret/srẽt/or } \\
\text { sreut/srut/ }\end{array}$ & $\begin{array}{l}\text { suddenly, un- } \\
\text { expectedly, at } \\
\text { once }\end{array}$ & $\mathrm{ka} / \mathrm{ka} /$ \\
\hline $\begin{array}{l}\text { teugageung / } \\
\text { twgagməy/ }\end{array}$ & supine, lying & linteueng /lintuəy/ \\
\hline bangsi /baysi/ & flute & suléng /suley/ \\
\hline $\begin{array}{l}\text { bunyoe / } \\
\text { buñ̃al }\end{array}$ & sound & $\mathrm{su} / \mathrm{su} /$ \\
\hline keuta /kuta/ & bed & peuratah /puratah/ \\
\hline rihan /rihan/ & sweet basil & $\begin{array}{l}\text { ön siaseh-aseh /on } \\
\text { siaseh-aseh/ }\end{array}$ \\
\hline bahgi /bahgi/ & part, fate & bagi /bagi/ \\
\hline $\begin{array}{l}\text { meutatah / } \\
\text { mütatah/ }\end{array}$ & sculpt, carve & uké /?ke/ \\
\hline $\begin{array}{l}\text { sambinoe / } \\
\text { sambiñ̃a/ }\end{array}$ & lovely, beautiful & $\begin{array}{l}\text { tari /tari/, canték / } \\
\text { cante?/, lagak / } \\
\text { laga?/ }\end{array}$ \\
\hline $\begin{array}{l}\text { seumurat / } \\
\text { sumũrat/ }\end{array}$ & tell story & $\begin{array}{l}\text { cerita /crrita/, peu- } \\
\text { gah /pugah/ }\end{array}$ \\
\hline pudoe /pudəa/ & gemstone & berlian /bərlijan/ \\
\hline & colorful & $\begin{array}{l}\text { warna-warni / } \\
\text { warnã-warnĩ// }\end{array}$ \\
\hline leubui /lubui/ & sleepy & teungeut /turnũt/ \\
\hline $\begin{array}{l}\text { ranom / } \\
\text { rañ̃m/ }\end{array}$ & friendly, gentle & $\begin{array}{l}\text { reumèh /rumẽh/, } \\
\text { leumah-leumbot / } \\
\text { lumãh lumbot/ }\end{array}$ \\
\hline 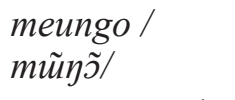 & buzzing & deungong /durว̃̃y/ \\
\hline $\begin{array}{l}\text { teugoe-goe / } \\
\text { tugragral }\end{array}$ & $\begin{array}{l}\text { remembered, } \\
\text { worried }\end{array}$ & $\begin{array}{l}\text { teubayang-bayang } \\
\text { /tubajan-bajay/, } \\
\text { teuingat-ingat / } \\
\text { turinãt-Pinãt/ }\end{array}$ \\
\hline $\begin{array}{l}\text { reuleueng / } \\
\text { rulwəy/ }\end{array}$ & cliff & $\begin{array}{l}\text { jeureulöng / } \\
\text { furuloy/ }\end{array}$ \\
\hline pari /pari/ & $\begin{array}{l}\text { spirit, name of } \\
\text { star }\end{array}$ & $\begin{array}{l}\text { jen /Jen/, bintang / } \\
\text { bintay/ }\end{array}$ \\
\hline tiji /tijil/ & fast & $\begin{array}{l}\text { bagaih /bagaih/, } \\
\text { leugat /lugat/, laju } \\
\text { /laju/ }\end{array}$ \\
\hline
\end{tabular}

Table 8 Non-archaic Alternative for Semi-archaic Words (Continued)

\begin{tabular}{|c|c|c|}
\hline Word & Meaning & $\begin{array}{l}\text { Non-archaic } \\
\text { alternative }\end{array}$ \\
\hline $\begin{array}{l}\text { gambang / } \\
\text { gambay/ }\end{array}$ & xylophone & silofon /silofon/ \\
\hline $\begin{array}{l}\text { meujeureulah } \\
\text { /müuzrulah/ }\end{array}$ & sparkling & $\begin{array}{l}\text { meukeulap-keulip } \\
\text { /mũkulap-kulip/ }\end{array}$ \\
\hline $\begin{array}{l}\text { seunaroe / } \\
\text { sunãroa/ }\end{array}$ & $\begin{array}{l}\text { comrade-in- } \\
\text { arms, friend }\end{array}$ & $\begin{array}{l}\text { rakan /rakan/, } \\
\text { ngon /ñ̃n } /\end{array}$ \\
\hline $\begin{array}{l}\text { reumbang / } \\
\text { rumbay/ }\end{array}$ & $\begin{array}{l}\text { exact, appropri- } \\
\text { ate, true }\end{array}$ & $\begin{array}{l}\text { teupat /tupat/, } \\
\text { beutöi /butoi/ }\end{array}$ \\
\hline $\begin{array}{l}\text { leunteng / } \\
\text { luntey/ }\end{array}$ & $\begin{array}{l}\text { beautiful, hand- } \\
\text { some }\end{array}$ & $\begin{array}{l}\operatorname{tari} / \text { tari/, lagak / } \\
\text { laga?/ }\end{array}$ \\
\hline $\begin{array}{l}\text { meulo-lo / } \\
\text { mũlolo/ }\end{array}$ & shiny & $\begin{array}{l}\text { meukilat-kilat/ } \\
\text { mũkilat-kilat/ }\end{array}$ \\
\hline $\begin{array}{l}\text { samlakoe / } \\
\text { samlakoz/ }\end{array}$ & handsome & $\begin{array}{l}\text { tari /tari/, lagak / } \\
\text { laga?/ }\end{array}$ \\
\hline kande /kandel & $\begin{array}{l}\text { candlestick, } \\
\text { candle holder }\end{array}$ & panyoet /pañ̃t/ \\
\hline $\begin{array}{l}\text { peundeng / } \\
\text { pundey/ }\end{array}$ & jewelry belt & $\begin{array}{l}\text { talo keuing /tao } \\
\text { ku?ion/ }\end{array}$ \\
\hline $\begin{array}{l}\text { keumala / } \\
\text { kumãla/ }\end{array}$ & jewel & $\begin{array}{l}\text { bate jimat /bate } \\
\text { jimat/ }\end{array}$ \\
\hline $\begin{array}{l}\text { tanjong / } \\
\text { tanjoy/ }\end{array}$ & cape, headland & - \\
\hline
\end{tabular}

The result of data analysis of Acehnese archaic words in Hikayat Prang Sabi shows that there are five archaic words and 49 semi-archaic words. The archaic words consist of one adjective, two nouns, and two verbs. In addition, the speakers chose 49 words as semi-archaic because they have not either used the words or known the meanings, and they rarely heard them. These semi-archaic words are mostly nouns, and others include adjectives and verbs. An interesting finding is revealed in the research regarding semiarchaic words. All respondents in both age groups have reported that they have ever both heard and used three words in the list, i.e., tiji 'fast', keumala 'jewel', and tanjong 'cape', 'headland'. Nevertheless, their classes and meanings that the respondents knew have changed into proper nouns, i.e., name of places. They are all names of sub-district in Pidie, i.e., Padang Tiji, Keumala, and Kembang Tanjong. No one of the respondents knows the real meanings and word classes.

The results of the research suggest that the Acehnese language has started to change in lexical level marked by the existence of some archaic words, as also revealed in other Austronesian languages such as Batak Toba language (Lumbantoruan, 2008) and Minangkabaunese (Azim \& Jufrizal, 2020). Although some words in the current research are semi-archaic, they are also expected to disappear from the language because none will use them in the near future.

Almost all Acehnese archaic and semi-archaic 
words have non-archaic alternatives. The alternatives for archaic and semi-archaic words in the research are commonly Acehnese words. Some alternatives are borrowed from bahasa Indonesia through either pure borrowing or naturalized borrowing. Interestingly, these borrowed alternatives are not found in Batak Toba. However, in the Pariaman dialect of Minangkabaunese, the speakers also use borrowed words from bahasa Indonesia as the replacements or alternatives for archaic and semi-archaic words. The borrowed alternative availability is suspected of what made most words become archaic in the current and previous studies. The status of Acehnese is now even more threatened because bahasa Indonesia has been dominantly used by the young generation (Ulfa, Isda, \& Purwati, 2018), and more parents have stopped speaking Acehnese to their children.

The result of data analysis of Acehnese archaic words in Hikayat Prang Sabi shows that there are five archaic words and 49 semi-archaic words. The archaic words consist of one adjective, two nouns, and two verbs. These words belong to those who have not known their meanings, and the respondents rarely heard them.

\section{CONCLUSIONS}

The research aims to find out which words used in Hikayat Prang Sabi are archaic and semi-archaic and whether those words have living-alternatives. Based on the research results, from 54 suspected archaic words, five of them (10\%) are archaic, and the rest $(90 \%)$ are semi-archaic. The parts of speech for archaic words are nouns, verbs, and adjectives, as are for semi-archaic words. No obvious difference is found among different ages of the respondents. Almost all of 5 archaic words and 49 semi-archaic words have alternative counterparts, which are still used. Most of the alternative words are Acehnese words. The rest is borrowed from bahasa Indonesia through either pure borrowing or naturalized borrowing.

As a suggestion based on the result of the research, revitalization for the archaic and semiarchaic words by increasing the textbooks using these archaic and semi-archaic words is needed. Moreover, considering that some archaic and semi-archaic words are not found in the dictionary. It is critical that the words be included in the later edition of the dictionary. In addition, the research is not a thorough study of Acehnese archaic words because only one source was used, i.e., Hikayat Prang Sabi. Therefore, it is strongly suggested that further research involving a bigger corpus be conducted. In addition, the archaicity in the research is concluded from the opinion of Acehnese speakers in one dialect. What is archaic in one dialect is possibly not archaic in others. Therefore, followup research can consider using more respondents covering all or varied Acehnese dialects.

\section{REFERENCES}

Al-Auwal, T. M. R. (2017). Reluctance of Acehnese youth to use Acehnese. Studies in English Language and Education, 4(1), 1-14. https://doi.org/10.24815/siele. v4i1.7000.

Antrushina, G. B., Afanasyeva, O. V., \& Morozova, N. N. (2008). English lexicology. Moscow: Drofa Publishing House.

Awe, B. I., \& Fanokun, P. S. (2018). Archaisms in legal contracts - A corpus-based analysis. European Journal of English Language and Literature Studies, 6(4), 5-20.

Azim, F., \& Jufrizal. (2020). The archaic words of Minangkabaunese found in Padang Lua. E-Journal of English Language and Literature, 9(1), 32-37.

Aziz, Z. A., \& Amery, R. (2016). The effects of a linguistic tsunami on the languages of Aceh. Studies in English Language and Education, 3(2), 103-111. https://doi. org/10.24815/siele.v3i2.4958.

Aziz, Z. A., Yusuf, Y. Q., \& Menalisa, M. (2020). National language or ethnic language? Young parents' language choice for their children in the Acehnese home. The International Journal of Communication and Linguistic Studies, 18(1), 21-35. https://doi. org/10.18848/2327-7882/CGP/v18i01/21-35.

Baxter, G., \& Croft, W. (2016). Modeling language change across the lifespan: Individual trajectories in community change. Language Variation and Change, 28(2), 129-173. https://doi.org/10.1017/ S0954394516000077.

Bowern, C. (2015). Linguistics: Evolution and language change. Current Biology, 25(1), 41-43. https://doi. org/10.1016/j.cub.2014.11.053.

Chairuddin, C. (2018). The shift of Acehnese language in pulau Kampai community, North Sumatra. Language Literacy, 2(1), 48-57. https://doi.org/10.30743/ 11.v2i1.478.

Clark, B. (2016). Relevance theory and language change. Lingua, 175, 139-153. https://doi.org/10.1016/j. lingua.2015.12.007.

Čolić,A. M. (2015). Word formation of blends. Mostariensia: Journal of Social Sciences and Humanities, 19(2), 21-36.

De Smet, H. (2016). How gradual change progresses: The interaction between convention and innovation. Language Variation and Change, 28(1), 83-102. https://doi.org/10.1017/S0954394515000186.

Ekawati, M. (2015). Pembelajaran menemukan unsurunsur intrinsik hikayat melalui model Student Teams Achievement Divisions (STAD) [The learning of discovers the intrinsic elements of hikayat through Student Teams Achievement Divisions (STAD) model]. Jurnal Pesona, 1(1), 50-58. https://doi. org/10.26638/jp.77.2080.

Hasjmy, A. (1977). Apa sebab rakyat Aceh sanggup berperang puluhan tahun melawan agresi Belanda (What is the cause of Acehnese people able to fight the Dutch aggression in decades). Jakarta: Bulan Bintang.

Jannedy, S., Poletto, R., \& Weldon, T. L. (1994). Language 
files: Materials for an introduction to language and linguistics. Columbus: Ohio State University Press.

Karagulova, B., Kushkimbayeva, A., Kurmanbayeva, S., Khan, A. A., \& Kaiyrbaeva, Z. (2016). Linguocultural description and formation of archaic words. Indian Journal of Science and Technology, 9(14), 1-6. https://doi.org/10.17485/ijst/2016/v9i14/91080.

Khadijah. (2013). Hikayat Indra Budiman telaah nilainilai religius (Kajian Hermeneutika). Jurnal Metamorfosa, 1(2), 22-32.

Kim, H., Sefcik, J. S., \& Bradway, C. (2017). Characteristics of qualitative descriptive studies: A systematic review. Research in Nursing \& Health, 40(1), 23-42. https://doi.org/10.1002/nur.21768.

Lubis, S. S. W. (2016). Sastra daerah dalam muatan pembelajaran Bahasa Indonesia di MI. Proceedings ARICIS; Ar-Raniry International Conference on Islamic Studies, 1, 477-489.

Lumbantoruan, N. (2008). Kajian kosa kata arkais bahasa Batak Toba. Medan: Sumatera Utara University.

Masri, H., Suprayitno, S., \& Ratna, R. (2018). War strategy done by Gayo and Alas people against Dutch colonial (1901-1912). Budapest International Research and Critics Institute (BIRCI-Journal): Humanities and Social Sciences, 1(2), 25-39. https:// doi.org/10.33258/birci.v1i2.10.

Moehkardi, R. R. D. (2017). Patterns and meanings of English words through word formation processes of acronyms, clipping, compound, and blending found in internet-based media. Jurnal Humaniora, 28(3), 324-338. https://doi.org/10.22146/jh.v28i3.22287.

Multazim, A., \& Nurdin, E. S. (2019). Word formation of photography terminologies. Journal of Language and Literature, 19(1), 43-54. https://doi.org/10.24071/ joll.2019.1901004.

Nassaji, H. (2015). Qualitative and descriptive research: Data type versus data analysis. Language Teaching Research, 19(2), 129-132. https://doi. org/10.1177/1362168815572747.

Nurhayati, D. A. W. (2016). Word formation processes and a technique in understanding waria slang Tulungagung. EFL Journal, 1(1), 59-87. https://doi. org/10.21462/eflj.v1i1.9.

Nushur, R. D., \& Astutie, D. D. (2019). The effectiveness of using Hikayat Prang Sabi in PjBL approach top improve students' critical thinking. Getsempena English Education Journal, 6(2), 285-296. https:// doi.org/10.46244/geej.v6i2.885.

Öztaş, S. (2018). A literary genre in value education in history courses: Poems. Journal of Education and Training Studies, 6(5), 34-39. https://doi.org/10.11114/jets. v6i5.3078.
Rababah, H. A. (2016). The translation of Al-Haramain (the two Holy Mosques) Fridays' sermons is unplanned language planning (management). Studies in Literature and Language, 12(3), 47-54. http://dx.doi. org/10.3968/8290.

Rahmi, R. (2015). The development of language policy in Indonesia. Englisia Journal, 3(1), 9-22. https://doi. org/10.22373/ej.v3i1.622.

Ratih, E., \& Gusdian, R. I. (2018). Word formation processes in english new words of Oxford English Dictionary (OED) online. CELTIC: A Journal of Culture, English Language Teaching, Literature, \& Linguistics, 5(2), 24-35. https://doi.org/10.22219/ celtic.v5i2.7617.

Rizka, B., \& Zainuddin. (2016). Lexical change with reference to social contact. Lingua Didaktika, 10(1), 1-8. https://doi.org/10.24036/ld.v10i1.6296.

Sankoff, G. (2018). Language change across the lifespan. Annual Review of Linguistics, 4(1), 297-316. https://doi.org/10.1146/annurevlinguistics-011817-045438.

Shabina. (2011). An ethnosemantic analysis of the cultural lexicon of Kashmiri language. Srinagar: University of Kashmir.

Sun, W. (2016). On word formation of computer English vocabulary. In Z. Hu \& Y. Sun (Eds.), Proceedings of the $20164^{\text {th }}$ International Conference on Management Science, Education Technology, Arts, Social Science and Economics (msetasse-16) (pp. 1537-1539). Paris, France: Atlantis Press. https://doi. org/10.2991/msetasse-16.2016.330.

Taslim, N. (2013). Narratives of war: Acehnese perception of the Prang Kaphe in $19^{\text {th }} / 20^{\text {th }}$ century colonial era. Malay Literature, 26(2), 139-153.

Traxel, O. M. (2012). Pseudo-archaic English: The modern perception and interpretation of the linguistic past. Studia Anglica Posnaniensia, 47(2-3), 41-58. https:// doi.org/10.2478/v10121-012-0003-y.

Triwahyuni, N., Imranuddin, \& Zahrida. (2018). An analysis of word formation encountered in medical terms in the Jakarta Post's articles. Journal of English Education and Teaching, 2(2), 93-102. https://doi. org/10.33369/jeet.2.2.93-102.

Ulfa, M., Isda, I. D., \& Purwati, P. (2018). The shift of Acehnese language: A sociolinguistic study to preserve regional languages. Studies in English Language and Education, 5(2), 161-174. https://doi. org/10.24815/siele.v5i2.8943.

Vejdemo, S., \& Hörberg, T. (2016). Semantic factors predict the rate of lexical replacement of content words. PLoS ONE, 11(1), 1-15. https://doi.org/10.1371/ journal.pone.0147924. 